\title{
CAPAIAN MILLENIUM DEVELOPMENT GOALS (MDG's) BERKAITAN DENGAN KESEHATAN ANAK DAN IBU DI PROVINSI RIAU
}

\author{
Rahmita Budiartiningsih \\ Dosen Universitas Riau \\ Email: rahmita_luthfi@yahoo.com
}

\begin{abstract}
The purpose of this study was to determine how the achievement of the MDGs relating to child and maternal health in the province of Riau. Samples were used that the MDGs program in Riau Province on the health aspects of the achievement of the MDG's in the province of Riau. The data collected will be described by using descriptive and cross tabulation techniques. The results showed the infant mortality rate per 1,000 live births in the province of Riau have under any other limitation of the MDG's are nine infant deaths per 1,000 live births MDG's target of 23 deaths per 1,000 live births. To decrease mortality rate per 1,000 live births Riau province is also under the limit, which is 5 mortality per 1,000 live births. For reducing maternal mortality by three-quarters of Riau province to reach its target in 2015, while for the achievement of maternity coverage attended by health personnel in the province of Riau has almost reached the target of the MDG's in 2013. The percentage of married women aged 15-49 years is still shows low considerable progress.Expected to further enhance the performance of the government in the field of maternal and child health.
\end{abstract}

Kata Kunci: Achievement of the MDGs, health of mother and child

\section{PENDAHULUAN}

Masalah kesehatan anak merupakan salah satu masalah utama bidang kesehatan di Indonesia.Derajat kesehatan anak mencerminkan derajat kesehatan bangsa, sebab anak sebagai penerus bangsa memiliki kemampuan yang dapat dikembangkan dalam meneruskan pembangunan bangsa. Berdasarkan alasan tersebut, masalah kesehatan anak diprioritaskan dalam perencanaan atau penataan pembangunan bangsa. ${ }^{1}$

Pembangunan di bidang kesehatan merupakan bagian integral dari pembangunan nasional Indonesia yang diatur dalam Sistem Kesehatan Nasional
(SKN). Pembangunan kesehatan bertujuan untuk agar semua aspek lapisan masyarakat dapat memperoleh pelayanan kesehatan secara merata dan murah. Dengan tujuan tersebut diharapkan akan tercapai derajat kesehatan masyarakat ang baik, yang pada giliranya memperoleh kehidupan yang sehat dan produktif. ${ }^{2}$

Kesehatan dan perbaikan gizi masyarakat berpengaruh pada peningkatan kesejahteraan sumber daya manusia. Faktorfaktor ini secara langsung akan berpengaruh terhadap kinerja fisik dan mental dari sumber daya manusia. Kualitas fisik dan mental yang bagus selanjutnya akan berpengaruh positif pada kapasitas kerja. ${ }^{3}$ 
Indonesia merupakan salahsatu negara yang menandatangani Satu paradigma pembangunan global, yakni Millenium Development Goals (MDGs) atau Tujuan Pembangunan Milenium. MDG's ini dideklarasikan pada bulan september tahun 2000 oleh 189 negara anggota Perserikatan Bangsa-Bangsa (PBB) di New York. Deklarasi MDG's merupakan hasil kesepakatan negaranegara maju dan berkembang di dunia.

Dalam konteks inilah, negara-negara anggota PBB kemudian mengadopsi MDG's. Setiap tujuan memiliki satu atau beberapa target beserta indikatornya. MDG's menempatkan pembangunan manusia sebagai fokus utama pembangunan, memiliki tenggang waktu dan kemajuan yang terukur. MDG's didasarkan pada konsensus dan kemitraan global, sambil menekankan tanggung jawab negara berkembang untuk melaksanakan pekerjaan rumah mereka, sedangkan negara maju berkewajiban mendukung upaya tersebut.

MDG's adalah upaya untuk memenuhi hak-hak dasar kebutuhan manusia. Visi pembangunan milenium ini adalah mempromosikan pembangunan manusia sebagai kunci untuk mencapai pengembangan sosial ekonomi yang berkelanjutan. Dalam tujuan ini, target harus mengacu ke tahun 2015. Secara ringkas, arah pembangunan disepakati secara global meliputi: (1) menanggulangi kemiskinan dan kelaparan; (2) mencapai pendidikan dasar untuk semua, (3) mendorong kesetaraan dan pemberdayaan perempuan; (4) menurunkan angka kematian anak;(5) meningkatkan kesehatan ibu; (6) mengurangi HIV/AIDS, malaria, dan penyakit menular lainnya; (7) memastikan kelestarian lingkungan hidup; (8) membangun kemitraan global untuk pembangunan

Indonesia sebagai salah satu negara yang ikut menyepakati sebuah pembanguann global Milenium Development Goals atau MDG's harus berkomitmen untuk mengintegrasikan MDG'S tersebut kedalam program-program pembangunan nasional. MDG'S bertujuan untuk mempercepat pembangunan manusia dan pemberantasan kemiskinan. Pencapaian tujuan dan target tersebut bukanlah semata-mata tugas pemerintah, tetapi juga merupakan tugas seluruh komponen bangsa Indonesia. Hal ini membuat pencapaian tujuan dan target MDG'S harus menjadi pembahasan seluruh masyarakat.

Seluruh dari target tersebut harus dicapai pada tahun 2015. Namun pada kenyataannya, Indonesia masih sangat kurang dalam pencapaian target tersebut. Sebagai gambaran kurangnya pencapaian target, dilihat dari target 4 dan target 5 dalam sektor kesehatan anak dan ibu. Dapat dilihat pada tabel tinjauan status pencapaian MDG's. 
Tabel 1.1

Tinjauan Status Pencapaian Target MDG'S Menurunkan Kematian Anak di Indonesia

Indikator Acuan Dasar $2007 \quad$ 2014Target MDG's Sumber

4.1

4.2
Angka Kematian97
Balita (AKBA)
per 1.000 kelahiran
hidup
Aangka Kematian 68
Bayi (AKB)
per 1.000 kelahiran
hidup

44

34

32

34

24
23

\section{Sumber: Indonesia MDG's Road Map 2010}

Salah satu tujuan MDG's yaitu menurunkan angka kematian balita sebesar dua pertiga dari tahun 1990 sampai dengan tahun 2015. Indikator angka kematian anak balita memperlihatkan penurunan. Pada tahun 1991, angka kematian balita mencapai 97 kematian per 1.000 kelahiran hidup. Pada tahun 2002/2003 angka kematian tersebut jauh menurun menjadi 46 kematian per 1.000 kelahiran hidup, dan pada tahun 2007 turun menjadi 44 kematian per 1.000 kelahiran hidup. Dan pada tahun 2014 juga mengalami penurunan menjadi 34 kematian per 1.000 kelahiran yang memungkinkan Indonesia akan mencapai target MDG's di tahun 2015.

Indikator angka kematian balita yang paling penting adalah angka kematian bayi (AKB) yang merupakan salah satu tolah ukur sejauh mana ketercapaian kesejahteraan rakyat sebagai hasil dari pelaksanaan pembangunan bidang kesehatan. Kegunaan lain dari $\mathrm{AKB}$ adalah sebagai alat monitoring situasi kesehatan, sebagai input perhitungan proyeksi penduduk, serta dapat juga dipakai untuk identifikasi kelompok penduduk yang mempunyai resiko kematian tinggi. (SKDI 2004).

Kesehatan anak di Indonesia terus mengalami peningkatan dari waktu ke waktu sebagai akibat dari perbaikan layanan kesehatan dan higiene, yang diiringi dengan penurunan angka kematian bayi dan anak. Pada tahun 1991, AKB mencapai 68 kematian per 1.000 kelahiran hidup. Pada tahun 20022003, angka tersebut menurun menjadi 35 kematian per 1.000 kelahiran hidup, dan pada tahun 2007 AKB tercatat 34 kematian per 1.000 kelahiran hidup. Pada tahun 2014 tercatat sebanyak 24 kematian per 1.000 kelahiran hidup. (SDKI berbagai tahun). dengan tingkat penurunan seperti itu, Indonesia diharapkan mampu mencapai target MDG's untuk menurunkan angka kematian bayi.Walaupun pencapaian telah begitu menggembirakan, tingkat kematian bayi di Indonesia masih tergolong tinggi jika 
dibandingkan dengan negara-negara anggota ASEAN, yaitu 4,6 kali lebih tinggi dari Malaysia, 1,3 kali lebih tinggi dari Filipina, dan 1,8 kali lebih tinggi dari Thailand.

Berdasarkan Indonesia MDG's Road Map tahun 2010, Angka Kematian Ibu (AKI) masih tetap tinggi. Kecendrungan yang ada, AKI terus menurun, namun perlu upaya dan kerja keras untuk mencapai target MDG's sebesar 102 kematian per 100.000 kelahiran hidup pada tahun 2015. Meskipun perkiraan angka kematian ibu bervariasi berdasarkan sumbernya, data SDKI 2007 mengungkapkan 228 kematian per 100.000kelahiran hidup untuk priode 2004 - 2007. Pada tahun 2014 tercatat 118 kematian per 100.000 kelahiran. Data ini menunjukkan penurunan secara bertahap dari 307 kematian per 100.000 kelahiran hidup pada tahun 1998 - 2002 dan 390 kematian per 100.000 kelahiran hidup pada tahun 1991. Sebagaimana diperkirakan oleh World Health Organization (WHO), 15 - 20 persen ibu hamil baik di negara maju maupun berkembang akan mengalami resiko tinggi dan kompikasi, maka akan diperkirakan setiap tahun 711.111 hingga 948.148 perempuan dan remaja putri Indonesia akan mengalami resiko tinggi komplikasi pada masa kehamilan, persalinan dan nifas.

Begitu juga halnya di Provinsi Riau, pemerintah daerah berupaya untuk meningkatkan kualitas sumber daya manusianya menuju MDG's di tahun 2015. Salah satu sasaran dan tujuan dari MDGS yang diharapkan dapat tercapai pada tahun 2015 adalah bidang kesehatan anak dan ibu, yang dapat dilihat dari indikator kematian bayinya.

Data Dinas Kesehatan Provinsi Riau tahun 2004 - 2013, menunjukkan angka kematian bayi di Provinsi Riau mengalami fluktiasi dari tahun ke tahun. Pada tahun 2004 angka kematian bayi sebesar 1.127 jiwa. Kemudian terjadi kenaikan yang signifikan tahun 2007 sebesar 1.359 jiwa dan pada tahun 2010 angka kematian bayi menurun menjadi 713 jiwa dan mengalami kenaikan lagi di tahun 2013 yaitu sebesar 1.170 jiwa.

Secara umum, bayi yang lahir dari ibu yang tinggal didaerah perkotaan mempunyai AKB yang lebih rendah daripada yang tinggal didaerah pedesaan, hal ini terkait dengan ketersediaan fasilitas yang lebih memadai dengan penduduk pedesaan.

Berdasarkan uraian diatas, maka perlu diketahui bagaimana capaian MDG's berkaitan dengan kesehatan anak dan ibu di Provinsi Riau dengan hipotesa diduga capaian MDG'berkaitan dengan kesehatan anak dan ibu di Provinsi Riau belum mencapai target MDG's di tahun 2015"

\section{METODE PENELITIAN}

\section{Lokasi Penelitian}

Sesuai dengan permasalahan dan tujuan penelitian ini, maka cakupan penelitian meliputi wilayah Provinsi Riau, dengan melihat banyaknya angka kematian yang tercatat dan mempertimbangkan 
tersedianya data yang dibahas maka penelitian ini dilakukan di Ibu Kota Provinsi Riau, Pekanbaru.

\section{Jenis dan Sumber Data}

Adapun data yang digunakan dalam penelitian ini adalah data sekunder. Data sekunder adalah data yang telah dikumpulkan oleh lembaga pengumpulan data dan dipublikasikan kepada masyarakat pengguna data (Kuncoro,2003:127).Data tersebut diperoleh dan bersumber dari instansi-instansi atau lembaga-lembaga yang berkaitan dengan penelitian ini,antara lain Badan Pusat Statistik Provinsi Riau dan Dinas Kesehatan Provinsi Riau.

\section{Teknik Pengumpulan Data}

Untuk memperoleh data yang diperlukan dalam penelitian ini digunakan teknik Studi Kepustakaan (library riset) yaitu dengan mengkaji literatur-literatur dan dokumen yang ada kaitannya dengan masalah yang dibahas. Permasalahan yang teliti kemudian dihubungkan dengan satu sama lainnya sehingga dapat diperoleh hasil dalam upaya menjawab permasalahan penerapan program MDG's di Provinsi Riau.Melalui teknik pengumpulan data sekunder yaitu dengan cara mencari data data yang diperoleh dari lembaga-lembaga pemerintahan seperti Biro Pusat Statistik(BPS) dan Dinas Kesehatan Provinsi Riau.

\section{Analisis Data}

Data yang telah dikumpulkan akan diuraikan dengan cara diskriptif dan teknik tabulasi silang. Analisis Deskriptif dilakukan dengan analisis data dengan temuan-temuan yang ada. Sedangkan tabulasi silang merupakan teknik statistik yang menjadikan dua atau lebih variabel secara bersamaan dan hasil dalam tabel tersebut mencerminkan distribusi dua atau lebih dari variabel yang mempunyai kategori terbatas atau nilai yang berbeda hasil analisis akan menjelaskan dan memberikan kesimpulan tentang capaian MDG's di Provinsi Riau.

Sampel yang digunakan yaitu program MDG's di Provinsi Riau pada aspek kesehatan terhadap pencapaian MDG's di Provinsi Riau. Capaian MDG's di lihat dari target indikator yang digunakan dalam MDG's,pada aspek kesehatan yaitu :

Target 4: Menurunkan Angka Kematian Balita sebesar dua-pertiganya dalam kurun waktu 1990-2015,indikator nya yaitu:

- Angka Kematian Balita (AKBA) per 1000 kelahiran.

- Angka Kematian Bayi (AKB) per 1000 kelahiran.

Target 5: Menurunkan angka kematian ibu sebesar tiga-perempatnya dalam kurun waktu 1990-2015, indikatornya: 
- Angka Kematian Ibu melahirkan (AKI) perseratus ribu kelahiran hidup.

- Proporsi kelahiran yang ditolong oleh tenaga kesehatan (\%)

- Proporasi perempuan 15-49 tahun berstatus kawin yang sedang menggunakan atau memakai alat keluarga berencana.

Dalam hal ini, Program MDG's dan indikator capaiannya dimasukkan dalam suatu tabulasi silang yang nantinya akan menghasilkan beberapa tabel sesuai dengan banyaknya pencapaian MDG's yang diteliti.

\section{PEMBAHASAN}

\section{Pertumbuhan Penduduk Riau}

Penduduk adalah semua orang yang berdomisili di wilayah geografis Indonesia selama enam bulan atau lebih dan atau mereka yang berdomisili kurang dari enam bulan dan tetapi bertujuan untuk menetap.

Pertumbuhan penduduk diakibatkan oleh tiga komponen yaitu: (1)fertilitas (kelahiran), yaitu istilah demografi diartikan sebagai hasil reproduksi yang nyata dari seorang perempuan atau sekelompok perempuan. Denga kata lain fertilitas ini menyangkut banyaknya bayi yang laihir hidup. (2) mortalitas (kematian), merupakan salah satu di antara tiga komponen demografi yang dapat mempengaruhi pertumbuhan pendudu. (3) migrasi, merupakan salah satu faktor dasar yang mempengaruhi petumbuhan penduduk. Peninjauan migrasi secara regional sangat penting untuk ditelaah.

Mengingat salah satu komponen yang mempengaruhi perkembangan penduduk adalah kelahiran (fertilitas) yang bersifat menambah jumlah penduduk, untuk itu menurut Sugiri, Indonesia harus memiliki Grand Desaign Pembangunan Kependudukan (GDPK) yang meliputi fertilitas, mortalitas, dan mobilitas penduduk. Dalam hal fertilitas adalah tercapainya kondisi penduduk tumbuh seimbang pada tahun 2015 dan terus berlanjut hingga tahun 2035. Untuk mencapai kondisi Penduduk Tumbuh Seimbang (PTS), diharapkan angka kelahiran total (TFR) 2,1 perperempuanatau Net Reproduction (NRR) sebesar 1 per perempuan pada tahun 2015. Kesejahteraan keluarga dan masyarakat akan lebih mudah tercapai apabila anak apada keluarga inti jumlahnya ideal "dua anak lebih baik", dengan cara mengatur jarak kelahiran dan jumlah anak. (Yuniarti, 2012).

Tabel 3.1

Penduduk Berdasarkan Angka Kelahiran Kematian, keluar dan Datang di Provinsi Riau Tahun 2013

\begin{tabular}{clllll}
\hline No & Kabupaten/Kota & Kelahiran & Kematian & Keluar & Datang \\
\hline 1 & Kampar & 16.051 & 227 & 1.638 & 1.567 \\
2 & Indragiri Hulu & 8.439 & 317 & 2.006 & 493
\end{tabular}




\begin{tabular}{clllll}
3 & Bengkalis & 11.505 & 10 & 2.576 & 3.864 \\
4 & Indragiri Hilir & 14.972 & 989 & 1.062 & 1.214 \\
5 & Pelalawan & 7.206 & 81 & 1.055 & 3.332 \\
6 & Rokan Hulu & 11.231 & 11 & 1.574 & 2.096 \\
7 & Rokan Hilir & 12.927 & 13 & 3.322 & 1.216 \\
8 & Siak & 8.807 & 38 & 2.424 & 6.905 \\
9 & Kuantan Singingi & 6.728 & 636 & 1.432 & 1.758 \\
10 & Kep. Meranti & 3.974 & 1.154 & 3.187 & 2.407 \\
11 & Pekanbaru & 20.931 & 29 & 5.500 & 9.366 \\
12 & Dumai & 5.892 & 29 & 1.881 & 2.819 \\
& Jumlah & $\mathbf{1 2 4 . 6 8 9}$ & $\mathbf{3 . 5 7 4}$ & $\mathbf{2 7 . 6 5 7}$ & $\mathbf{3 7 . 0 3 7}$ \\
\hline
\end{tabular}

Sumber: Dinas Ketenagakerjaan, Transmigrasi, dan Kependudukan, 2013

Tabel diatas menjelaskan angka kelahiran, kematian, pindah dan datang di Provinsi Riau pada tahun 2013. Angka Kelahiran di Provinsi Riau sebesar 124.689 jiwa. dan angka kematian di Provinsi Riau sebesar 3.574 jiwa di tahun 2013. Dan migrasi bersih yang ada di Provinsi Riau yaitu 9.380.

Target MDG's Menurunkan Angka Kematian Anak

Target MDG's dibidang kematian anak yang utama adalah menurunkan angka kematian balita sebesar dua-pertiganya dalam kurun waktu 1990-2015, yaitu; (1) Angka Kematian Balita (AKBA) per 1.000kelahiran hidup; (2) Angka Kematian Bayi (AKB) per 1.000 kelahiran bayi. Keadaan dan kecendrungan capaian MDG's di bidang kesehatan anak di Provinsi Riau pada Indikator Angka Kematian Balita (AKBA) per 1.000 kelahiran hidup, bisa dilihat pada tabel di bawah ini:

Tabel 4.1

Angka Kematian Balita (AKBA) per 1.000 Kelahiran Hidup di Provinsi Riau Tahun 2004-2013

\begin{tabular}{lrrrr}
\hline No & Tahun & \multicolumn{1}{c}{$\begin{array}{c}\text { Jumlah } \\
\text { Kelahiran }\end{array}$} & $\begin{array}{c}\text { Jumlah Kematian } \\
\text { Balita }\end{array}$ & $\begin{array}{c}\text { Angka Kematian } \\
\text { Balita per 1.000 } \\
\text { Kelahiran }\end{array}$ \\
& & & & 3 \\
\hline 1 & 2004 & 93.053 & 287 & 1 \\
2 & 2005 & 95.734 & 124 & 0 \\
3 & 2006 & 106.677 & 25 & 2 \\
4 & 2007 & 115.826 & 178 & 1 \\
5 & 2008 & 123.927 & 101 & 14 \\
6 & 2009 & 116.266 & 1.570 & 6 \\
7 & 2010 & 112.851 & 636 & 8 \\
8 & 2011 & 132.897 & 634 & 10 \\
9 & 2012 & 128.663 & 732 & 5 \\
10 & 2013 & 124.689 & 632 &
\end{tabular}

\section{Sumber: Dinas Kesehatan Provinsi Riau dan Data Olahan}


AKBA menggambarkan tingkat permasalahan kesehatan anak dan faktorfaktor lain yang berpengaruh terhadap kesehatan anak balita seperti gizi, sanitasi, penyakit infeksi dan kecelakaan.Angka Kematian Balita dikhususkan untuk Anak Balita (AKBA) umur 1-5 tahun adalah Aangka Anak Kematian Balita (AKBA) per 1.000 kelahiran. AKBA dapat memberikan gambaran status kelangsungan hidup di suatu wilayah. Di tahun 2004 Angka Kematian Balita di Provinsi Riau mencapai 287 per kelahiran hidup dan per 632 kelahiran hidup dei tahun 2013 berdasarkan pengumpulan data sektor dapat ditemukan hanya ada 3 kematian per 1.000 kelahiran hidup di tahun 2004, sebanyak 5 kematian per 1.000 kelahiran hidup di tahun 2015.

Tabel 4.2

Capaian MDG's dibidang Kesehatan di Provinsi Riau pada Indikator Angka Kematian Balita (AKBA) Tahun 2004 - 2013

\begin{tabular}{lcccc}
\hline No & Tahun & AKBA & \multicolumn{2}{c}{ Capaian MDG's } \\
& & & Target & Status Pencapaian \\
\hline 1 & 2004 & 3 & 32 & Sudah Tercapai \\
2 & 2005 & 1 & 32 & Sudah Tercapai \\
3 & 2006 & 0 & 32 & Sudah Tercapai \\
4 & 2007 & 2 & 32 & Sudah Tercapai \\
5 & 2008 & 1 & 32 & Sudah Tercapai \\
6 & 2009 & 14 & 32 & Sudah Tercapai \\
7 & 2010 & 6 & 32 & Sudah Tercapai \\
8 & 2011 & 8 & 32 & Sudah Tercapai \\
9 & 2012 & 10 & 732 & Sudah Tercapai \\
10 & 2013 & 5 & 632 & Sudah Tercapai \\
\hline
\end{tabular}

Sumber: Data Olahan, 2014

Berdasarkan batasan batas capaian indikator MDG's Angka Kematian Balita diharapkan berada di bawah 34 per 1.000 kelahiran hidup. Dengan jumlah kematian anak balita di Provinsi Riau di tahun 2004 sebanyak 287 dibagi dengan jumlah kelahiran hidup 93.053 dikali 1.000 maka diperoleh kurang lebih 3 kematian per 1.000 kelahiran hidup, masih berada dibawah batasan MDG's, demikian juga di tahun 2013 kematian anak balita hanya kurang lebih 5 kematian per 1.000 keelahiran hidup. Artinya, sudah cukup rendfah kejadian kematian anak balita di Provinsi Riau di tahun $2004-2013$.

Dari tabel 4.2 dapat di lihat gambaran angka kematian balita di Provinsi Riau tahun 2004 - 2013. Jumlah kematian balita di Provinsi Riau fluktuatif, dari 3 di tahun 2004 menurun di tahun 2005 sebesar 1 per 1.000 kelahiran, kemudian terus mengalami penurunan dari 0 per 1.000 kelahiran hidup meningkat di tahun 2007 menjadi 2 per seribu kelahiran hidup, menurun lagi di 
tahun 2008 yaitu 1 per 1.000 kelahiran hidup, naik lagin secara signifikan di tahun 2009 menjadi 14 kematian per 1.000 kelahiran, menurun lagi cukup signifikan di tahun 2010 menjadi 6 per 1.000 kelahiran hidup, naik lagi menjadi 8 per 1.000 kelahiran hidup di tahun
2011. Tahun 2012 meningkat menjadi 10 per 1.000 kelahiran hidup. Capaian MDG's dibidang kesehatan (Kematian Anak) di Provinsi Riau pada indikator Angka Kematian Bayi (AKB) per 1.000 kelahiran hidup dapat dilihat dari tabel dibawah ini:

Tabel 4.3

Angka Kematian Bayi (AKB) per 1.000 Kelahiran Hidup

Tahun 2004 - 2003

\begin{tabular}{lrrrr}
\hline No & Tahun & $\begin{array}{c}\text { Jumlah } \\
\text { Kelahiran }\end{array}$ & $\begin{array}{c}\text { Jumlah Kematian } \\
\text { Bayi }\end{array}$ & $\begin{array}{c}\text { Angka Kematian } \\
\text { Bayi per 1.000 } \\
\text { Kelahiran }\end{array}$ \\
\hline 1 & 2004 & 93.053 & 1.127 & 12 \\
2 & 2005 & 95.734 & 1.257 & 13 \\
3 & 2006 & 106.677 & 1.272 & 12 \\
4 & 2007 & 115.826 & 1.359 & 12 \\
5 & 2008 & 123.927 & 1.345 & 11 \\
6 & 2009 & 116.266 & 1.345 & 12 \\
7 & 2010 & 112.851 & 889 & 8 \\
8 & 2011 & 132.897 & 859 & 11 \\
9 & 2012 & 128.663 & 708 & 9 \\
10 & 2013 & 124.689 & 1.170 & 9 \\
\hline
\end{tabular}

Sumber: Dinas Kesehatan Provinsi Riau, 2004-2013 dan Data Olahan, 2014

Dari tabel di atas, dapat kita lihat bahwa Angka Kematian Bayi (AKB) Provinsi Riau mengalami penurunan dan kenaikan. Pada tahun 2004 jumlah bayi mati sebesar 1.127 orang atau memiliki angka kematian bayi per 1.000 kelahiran sebesar 12 . Terjadi

Tabel 4.4

Capaian MDG's dibidang Kesehatan di Provinsi Riau pada Indikator Angka Kematian Balita (AKB) Tahun 2004 - 2013

\begin{tabular}{ccccc}
\hline No & Tahun & AKB & & Capaian MDG's \\
& & & Target & Status Pencapaian \\
\hline 1 & 2004 & 12 & 23 & Sudah Tercapai \\
2 & 2005 & 13 & 23 & Sudah Tercapai \\
3 & 2006 & 12 & 23 & Sudah Tercapai \\
4 & 2007 & 12 & 23 & Sudah Tercapai
\end{tabular}




\begin{tabular}{ccccc}
5 & 2008 & 11 & 23 & Sudah Tercapai \\
6 & 2009 & 12 & 23 & Sudah Tercapai \\
7 & 2010 & 18 & 23 & Sudah Tercapai \\
8 & 2011 & 11 & 23 & Sudah Tercapai \\
9 & 2012 & 9 & 23 & Sudah Tercapai \\
10 & 2013 & 9 & 632 & Sudah Tercapai \\
\hline
\end{tabular}

Sumber: Data Olahan, 2014

Berdasarkan batasan capaian

Indikator penilaian untuk penurunan indikator MDG's angka kematian bayi diharapkan dibawah 23 kematianper 1.000 kelahiran hidup. Dengan angka kematian bayi di Provinsi Riau tahun 2004 sebanyak 1.127 jiwa dibagi dengan jumlah kelahiran hidup di kali 1.000 kelahiran hidup, masih dibawah batasan MDG's, demikian juga di tahun 2013 kematian bayi hanya ditemukan 9 kematian per 1.000 kelahiran hidup. Diperkirakan kematian bayi di Provinsi Riau masih lebih banyak jika dibandingkan dengan yang ditemukan atau yang dilaporkan oleh puskesmas.

Target MDG's Meningkatkan Kesehatan Ibu angka kematian $\mathrm{u}$ sebesar tiga perempatnya dalam kurun waktu 1990 - 2015 ialah sebagai berikut: (1) angka Kematian Ibu Melahirkan (AKI) per 100.000 kelahiran; (2) proporsi kelahiran yang ditolong oleh tenga kerja kesehatan (\%); (3) proporsi perempuan 15 49 tahun berstatus kawin yang sedang menggunakan atau memakai alat keluarga berencana.

Keadaan dan kecendrungan capaian MDG's dibanding kesehatan di Provinsi Riau pada indikator Angka Kematian Ibu melahirkan (AKI) per 100.000 kelahiran hidup, bisa dilihat pada tabel dibawah ini:

\section{Tabel 4.5}

Angka Kematian Ibu (AKI) Melahirkan per 100.000 Kelahiran Hidup Tahun Provinsi Riau tahun $2004-2003$

\begin{tabular}{cccc}
\hline No & Tahun & Angka Lahir Hidup & Jumlah Kematian Ibu \\
\hline 1 & 2004 & 93.053 & 127 \\
2 & 2005 & 95.734 & 155 \\
3 & 2006 & 106.677 & 179 \\
4 & 2007 & 115.826 & 199 \\
5 & 2008 & 123.927 & 201 \\
6 & 2009 & 116.266 & 208 \\
7 & 2010 & 112.851 & 173 \\
8 & 2011 & 132.897 & 161 \\
9 & 2012 & 128.663 & 158 \\
10 & 2013 & 124.689 & 135 \\
\hline
\end{tabular}

\section{Sumber: Dinas Kesehatan Provinsi Riau, 2004-2013}

Angka Kematian Ibu (AKI)

pada saat hamil atau selama 42 hari sejak merupakan banyaknya kematian perempuan teriminasi kehamilan tanpa memandang 
lama atau tempat persalinan, yang disebabkan karena kehamilannya atau pengelolaannya, dan bukan karena sebabsebab lain per 100.000 kelahiran hidup .

Angka Kematian Ibu Maternal menggambarkan status gizi dan kesehatan,

Tabel 4.6

Capaian MDG's dibidang kesehatan di Provinsi Riau Pada Indikator Angka Kematian Ibu (AKI) Melahirkan Tahun 2004-2013

\begin{tabular}{ccccc}
\hline No & Tahun & AKI & Target & Capaian MDG's \\
& & & 102 & \\
& & & 102 & $\checkmark$ \\
\hline 1 & 2004 & 133 & 102 & $\checkmark$ \\
2 & 2005 & 162 & 102 & $\checkmark$ \\
3 & 2006 & 168 & 102 & $\checkmark$ \\
4 & 2007 & 172 & 102 & $\checkmark$ \\
5 & 2008 & 169 & 102 & $\checkmark$ \\
6 & 2009 & 179 & 102 & $\checkmark$ \\
7 & 2010 & 153 & 102 & $\checkmark$ \\
8 & 2011 & 121 & 102 & $\checkmark$ \\
9 & 2012 & 123 & & \\
10 & 2013 & 108 & & \\
\hline
\end{tabular}

Sumber: Data Olahan, 2014

Dari tabel diatas dapat kita lihat angka kematian ibu per 100.000 kelahiran hidup di Provinsi Riau. Capaian MDG's untuk angka kematian ibu target yang telah ditetapkan oleh Bappenas di tahun 2015 yaitu sebesar 102 kematian per 100.000 kelahiran hidup. Dari tabel diatas Provinsi Riau belum mencapai target yang telah ditetapkan. Akan tetapi di tahun 2013 angka kematian ibu per 100.000 kelahiran sebesar 108. Angka ini tingkat pelayanan kesehatan terhadap ibu hamil,ibu melahirkan dan masa nifas. AKI sampai saat ini baru diperoleh dari surveisurvei terbatas sudah mendekati target MDG's yaitu sebesar 102 kematian per 100.000 kelahiran hidup. Yang berarti untuk angka kematian ibu di Provinsi Riau tahun 2013 akan mencapai target MDG's 2015.

Keadaan dan kecendrungan capaian MDG's dibidang kesehatan ibu di Provinsi Riau pada indikator proporsi kelahiran yang ditolong oleh tenaga kesehatan (\%),bisa dilihat pada tabel dibawah ini.

Tabel 4.7

Presentase Proporsi Kelahiran yang Ditolong Oleh Tenaga Kesehatan Provinsi Riau Tahun 2004-2013

\begin{tabular}{|c|c|c|c|c|}
\hline \multirow[t]{2}{*}{ No } & \multirow[t]{2}{*}{ Tahun } & \multirow[t]{2}{*}{$\begin{array}{l}\text { Jumlah } \\
\text { Persalinan }\end{array}$} & \multicolumn{2}{|c|}{$\begin{array}{c}\text { Proporsi Kelahiran yang Ditolong Oleh Tenaga } \\
\text { Kesehatan }\end{array}$} \\
\hline & & & Jumlah & Persentase (\%) \\
\hline 1 & 2004 & 118.101 & 85.303 & 72 \\
\hline
\end{tabular}




\begin{tabular}{ccccc}
\hline 2 & 2005 & 120.176 & 85.986 & 71 \\
3 & 2006 & 127.382 & 95.919 & 75 \\
4 & 2007 & 124.733 & 96.118 & 78 \\
5 & 2008 & 136.530 & 102.081 & 75 \\
6 & 2009 & 125.049 & 107.763 & 86 \\
7 & 2010 & 133.612 & 110.601 & 83 \\
8 & 2011 & 138.503 & 113.693 & 82 \\
9 & 2012 & 131.689 & 115.771 & 88 \\
10 & 2013 & 130.728 & 117.374 & 89 \\
\hline
\end{tabular}

Sumber: Dinas Kesehatan Provinsi Riau 2004 - 2013

Pelayanan kesehatan terhadap ibu bersalin berupa pertolongan persalinan oleh tenaga kesehatan. Cakupan ibu bersalin yang ditolong oleh tenaga kesehatan di Provinsi Riau dari tahun 2004 sampai dengan tahun 2013 fluktuatif. Tahun 2004 sebesar 72\% menurun di tahun 2005 sebesar 71\%, dan meningkat di tahun 2006 menjadi $75 \%$ dan meningkat lagi tahun 2007 menjadi 78\%, tetapi di tahun 2008 sedikit mengalami penurunan menjadi $75 \%$,meningkat lagi di tahun 2009 menjadi 86\% meningkat lagi di tahun 2010 menjadi 83\%. Meningkat lagi di tahun 2011 sebesar 82 dan terus meningkat hingga tahun 2013 yaitu sebesar 80\%. Berikut adalah target pencapaian persalinan yang ditolong oleh tenaga medis di Provinsi Riau.

Tabel 4.8

Capaian MDG's dibidang Kesehatan Ibu di Provinsi Riau Pada Indikator Proporsi Kelahiran yang Ditolong Oleh Tenaga Kesehatan (\%)

\begin{tabular}{ccccc}
\hline No & Tahun & $\begin{array}{c}\text { Proporsi Kelahiran yang } \\
\text { Ditolong Oleh Tenaga } \\
\text { Kesehatan (\%) }\end{array}$ & $\begin{array}{c}\text { Capaian MDG's } \\
\text { Target }\end{array}$ & Belum Tercapai \\
\hline 1 & 2004 & 72 & 90 & $\checkmark$ \\
2 & 2005 & 71 & 90 & $\checkmark$ \\
3 & 2006 & 75 & 90 & $\checkmark$ \\
4 & 2007 & 78 & 90 & $\checkmark$ \\
5 & 2008 & 75 & 90 & $\checkmark$ \\
6 & 2009 & 86 & 90 & $\checkmark$ \\
7 & 2010 & 83 & 90 & $\checkmark$ \\
8 & 2011 & 82 & 90 & $\checkmark$ \\
9 & 2012 & 88 & 90 & $\checkmark$ \\
10 & 2013 & 89 & 90 & $\checkmark$ \\
\hline
\end{tabular}

Sumber: Data Olahan, 2014

Berdasarkan tabel diatas proporsi

diatas Provinsi Riau di tahun 2013 sudah kelahiran yang ditolong oleh tenaga mendekati angka capaian MDG's yaitu kesehatan mengalami peningkatan secara bertahap. Capaian MDG's untuk proporsi kelahiran yang ditolong oleh tenaga kesehatan target yang harus dicapai untuk tahun 2015 sebesar 90\%. Dilihat dari tabel dengan angka $89 \%$.

Meskipun secara provinsi target persalinan tenaga kesehatan akan tercapai, namun bila diperhatikan hasil pencapaian berdasarkan kabupaten/kota maka masih 
banyak kabupaten/kota yang belum mencapai target, ini artinya dibeberapa kabupaten/kota di Provinsi Riau masih banyak persalinan yang dilakukan bukan dengan tenaga kesehatan.

Faktor yang menyebabkan masih rendah nya cakupan ibu bersalin yang ditolong oleh tenaga kesehatan di akibatkan jauhnya fasilitas kesehatan dari desa atau tempat tinggal ibu bersalin. Permasalahan tenaga bidan yang belum mencukupi dan belum merata penyebarannya merupakan tantangan yang perlu di jawab dengan segera. Pada daerah-daerah yang relatif terpencil dan tertinggal, masyarakat mengalami kesulitan mengakses bidan oleh karenanya sangat tergantung pada dukun beranak.

Keadaan dan kecendrungan capaian MDG's dibidang kesehatan ibu di Provinsi Riau pada indikator proporsi perempuan berstatus kawin yang sedang menggunakan atau memakai alat keluarga berencana,bisa dilihat pada tabel dibawah ini:

Tabel 4.9

Capaian MDG's dibidang Kesehatan Ibu di Privinsi Riau Pada Indikator Proporsi Perempuan Berstatus Kawin yang Sedang Menggunakan Atau Memakai Alat Kontrasepsi Atau Keluarga Berencana.

\begin{tabular}{ccccc}
\hline No & Tahun & $\begin{array}{c}\text { Persentase Perempuan } \\
\text { yang Sedang } \\
\text { Menggunakan Atau } \\
\text { Memakai Alat } \\
\text { Keluarga Berencana }\end{array}$ & $\begin{array}{c}\text { Capaian MDG's } \\
\text { Target }\end{array}$ & Belum Tercapai \\
\hline 1 & 2004 & 50 & 65 & \\
2 & 2005 & 57 & 65 & $\checkmark$ \\
3 & 2006 & 54 & 65 & $\checkmark$ \\
4 & 2007 & 54 & 65 & $\checkmark$ \\
5 & 2008 & 39 & 65 & $\checkmark$ \\
6 & 2009 & 57 & 65 & $\checkmark$ \\
7 & 2010 & 56 & 65 & $\checkmark$ \\
8 & 2011 & 57 & 65 & $\checkmark$ \\
9 & 2012 & 58 & 65 & $\checkmark$ \\
10 & 2013 & 59 & & \\
\hline
\end{tabular}

\section{Sumber: Data Olahan, 2014}

Dari tabel diatas dapat kita lihat

bahwa proporsi perempuan berstatus kawin yang sedang menggunakan atau memakai alat kontrasepsi atau keluarga berencanabelum mencapai target. Namun pada tahun2013 persentase perempuan berstatus kawin yang sedang menggunakan atau memakai alat kontrasepsi atau keluarga berencana sebesar 59\%. Persentase tersebut mendekati target MDG's di tahun 2015. Yang berarti target MDG's untuk proporsi perempuan berstatus kawin yang sedang menggunakan atau memakai alat kontrasepsi atau keluarga berencana akantercapai di tahun 2015.

\section{KESIMPULAN}

Berdasarkan uraian diatas, maka dapat ditarik kesimpulan sebagai berikut; 
Pertama, pada target menurunkan angka kematian bayi di Provinsi Riau yang indikatornya angka kematian balita per 1000 kelahiran hidup dan angka kematian bati per 1000 kelahiran hidup sudah berada di bawah batasan MDG's. Diperkirakan jumlah kematian anak di Provinsi Riau masih lebih banyak jika dibandingkan dengan temuan atau yang dilaporkan oleh puskesmas

Kedua, pada target meningkatkan kesehatan ibu di Provinsi Riau masih ada beberapa target yang sudah hampir mendekati MDG's da nada juga belum mencapai target MDG's yaitu seperti angka kematian ibu melahirkan sudah hampir mendekati target MDG's. pada indikator proporsi cakupan ibu bersalin yang ditolong oleh tenaga kesehatan sudah mencapai target MDG's tetapi apabila dilihat dari kabupaten/kota masih ada beberapa yang belum mencapai target yaitu seperti Kabupaten Kepulauan Meranti, Indragiri Hilir dan Kuantan Sengingi. Dan pada indikator proporsi perempuan usia kawin 1549 tahun yang sedang menggunakan atau memakai alat kontrasepsi masih menunjukkan perkembangan yang lambat.

\section{SARAN}

Berdasarkan hasil dan pembahasan yang telah dipaparkan, maka penulis merekomendasikan beberapa saran yaitu;

Pertama, kepada pemerintah Provinsi Riau melalui Dinas Kesehatan Kabupaten/Kota dapat mempertahankan capaian MDG's dalam indikator-indikator yang telah mencapai target MDG's.

Kedua, pemerintah melalui Dinas Kesehatan Kabupaten/Kota atau organisasi yang mempunyai perhatian kepada kesehatan anak dan ibu dapat memberikan sosialisasi pentingnya menjaga kesehatan anak dan ibu agar dapat mempertahankan capaian MDG's yang telah dicapai.

\section{Endnotes:}

\footnotetext{
${ }^{1}$ Hidayat, Aziz Alimul. 2008. Pengantar Ilmu Kesehatan. Jakarta: Salemba Medika. hal.2.

${ }^{2}$ Badan Pusat Statistik. 2003. Riau Dalam Angka. BPS Pekanbaru. hal. 92.

${ }^{3}$ Mulyadi, Subri. 2003. Ekonomi Sumber Daya Manusia. Jakarta: PT. Grafindo Persada. hal.207.
}

\section{DAFTAR PUSTAKA}

Badan Perencanaan Pembangunan Nasional. 2007. Laporan Pencapaian Millenium Development Goal's Indonesia 2007. Lampiran 1

Badan Pusat Statistik. 2003. Riau Dalam Angka. BPS Pekanbaru.

Hidayat, Aziz Alimul. 2008. Pengantar Ilmu Kesehatan. Jakarta: Salemba Medika

Juhardi, Riski Robi. 2011. Studi Empiris Capaian MDG's di Provinsi Riau. Jurnal Sosial Ekonomi Pembangunan. Vol. 1 No.3

Mulyadi, Subri. 2003. Ekonomi Sumber Daya Manusia. Jakarta: PT. Grafindo Persada.

Survei Demografi dan Kesehatan Indonesia (SDKI). 2007. Survei Demografi dan Kesehatan Indonesia. Indonesia 
marwah, Vol. XV No.1 Juni Th. 2016 